Article

\title{
Enhancing Social Resilience of the Coastal Fishing Communities: A Case Study of Hilsa (Tenualosa Ilisha H.) Fishery in Bangladesh
}

\author{
Mohammad Mojibul Hoque Mozumder ${ }^{1, *(\mathbb{D}, \text { Md. Abdul Wahab }}{ }^{2}$, Simo Sarkki ${ }^{3}$, \\ Petra Schneider ${ }^{4}\left({ }^{-}\right.$and Mohammad Mahmudul Islam ${ }^{5}$ \\ 1 Helsinki Institute of Sustainability Science (HELSUS), Fisheries and Environmental Management Group, \\ Faculty of Biological and Environmental Sciences, University of Helsinki, 00014 Helsinki, Finland \\ 2 WorldFish, Bangladesh and South Asia Office, House\# 22B, Road\# 07, Block-F, Banani, Dhaka 1213, \\ Bangladesh; A.Wahab@cgiar.org \\ 3 Cultural Anthropology, University of Oulu, P.O. Box 1000, FI-90014 Oulu, Finland; simo.sarkki@oulu.fi \\ 4 Department for Water, Environment, Civil Engineering and Safety, University of Applied Sciences \\ Magdeburg-Stendal, Breitscheidstraße 2, D-39114 Magdeburg, Germany; petra.schneider@hs-magdeburg.de \\ 5 Department of Coastal and Marine Fisheries, Sylhet Agricultural University, Sylhet 3100, Bangladesh; \\ mahmud.cmf@sau.ac.bd \\ * Correspondence: mohammad.mozumder@helsinki.fi; Tel.: +35-8400491395
}

Received: 20 June 2018; Accepted: 27 September 2018; Published: 29 September 2018

check for updates

\begin{abstract}
Social resilience is an essential aspect of sustainability in environmental management, especially in poor resource-dependent communities. To better understand the dynamics of social resilience, we have conducted a primarily qualitative study of communities dependent on hilsa fishing in two coastal villages in southern Bangladesh. This study applies concepts of social-ecological system (SES), social resilience and co-management in outlining our qualitative data and framing its interpretation. Our findings show that while the establishment of hilsa sanctuary areas has enhanced the previously low ecological sustainability of local small-scale fishing, the management of this program has challenged the social resilience of hilsa fishers by creating new inequalities in the distribution of power and privilege, in terms of the ways in which seasonal fishing bans are enforced and compensation for income loss during the ban periods is distributed. Based on our findings, we suggest specific measures for strengthening social resilience at the local level, including building community networks, developing community infrastructures, updating existing rules and regulations, providing alternative means of generating income for fishers during the crisis periods (e.g. natural disasters and fishing ban periods) and more active sharing of responsibility between stakeholders and government for management of the hilsa fishery. These findings are also applicable to understanding the issues beyond rules and regulations that co-management arrangements need to address in order to be successful and to enhancing the function of co-management arrangements in improving social resilience within resource-dependent communities.
\end{abstract}

Keywords: hilsa; small-scale fishing communities; social-ecological systems; social resilience; co-management

\section{Introduction}

Natural resources of the globe face various sustainability challenges, including degradation, unbalanced and unfair use and exploitation [1,2]. The harms and negative impacts on the natural environment, resulting from poorly managed sustainability challenges, negatively affect human society as well, through a variety of exchange processes and complex feedbacks [3]. Usually the poor are 
most affected by these perturbations. Including those most dependent on local resources in local decision-making processes-counting the poor and those who lack alternative options to enhance their well-being as significant stakeholders-for example via co-management arrangements, is often considered as a means of addressing the inequity resulting from current resource use patterns [4]. The consequences of such sustainability challenges can be far-reaching. For example, about a third of the world's fisheries are overexploited [5,6]. For overexploited fisheries, overfishing threatens social resilience on all levels, from the global to local scale, especially for those who directly rely on the ocean for livelihoods, food security and well-being [6,7]. Therefore, exploring the links between the status of fish stocks and the social resilience of local communities depending on those stocks is essential, especially in developing countries and resource-dependent communities.

In Bangladesh, the coastal resources, including open water fisheries and small-scale fisheries, significantly contribute to the national economy as well as promoting the socioeconomic well-being of impoverished coastal fishing communities [8]. Bangladesh is one of the world's leading fish producing countries with a total production of 4.134 million metric tons in 2016-2017 [9], of which the hilsa (Tenualosa ilisha) catch makes up approximately 12\% [9]. The hilsa fishery has a total annual value of USD 1.3 billion, thus accounting for more than 1\% of Bangladesh's total GDP and employing approximately 2.5 million people directly and indirectly in the process [10]. Thus, hilsa has become the most valuable single-species fishery of Bangladesh. Hilsa is also crucial to the Bangladeshi diet for its nutritional value, as it is rich in micronutrients and omega-3 fatty acids [11]. The social and cultural significance of hilsa is also immense. Hilsa is honoured as the national fish of Bangladesh and considered essential in many religious, social and festive events [12]. Recently hilsa has been declared as a Geographical Indicator (GI) for Bangladesh.

Hilsa is an anadromous clupeid endemic to the Bay of Bengal, the Indian Ocean and the Arabian Sea and is well-distributed in the Ganges-Brahmaputra-Meghna drainage systems of India and Bangladesh [13]. In Myanmar, the majority of inland hilsa catch comes from the Irrawaddy and the Tanintharyi rivers [14]. The hilsa fishery generates employment and income for millions of people in India, Bangladesh and Myanmar, worth over US\$ 2 billion [15]. The species has a significant market demand, with a global average annual catch of about 0.72 million tons, of which approximately $50 \%$ to $60 \%$ comes from Bangladesh, $20 \%$ to $25 \%$ from Myanmar, $15 \%$ to $20 \%$ from India and 5\% to $10 \%$ from other countries (e.g., Iraq, Kuwait, Malaysia, Thailand and Pakistan) [16]. In recent decades, the availability of hilsa has drastically dwindled in aquatic systems across this region due to anthropogenic pressures: mainly intensive fishing, pollution and river obstruction by dams and barrages. Climate change may also be contributing to the declining populations [17]. The decline in hilsa catch provoked the Government of Bangladesh to adopt a Hilsa Fisheries Management Action Plan (HFMAP) in 2003. HFMAP defines conservation measures, including scientific fish stock assessments, no-take sanctuaries for juveniles during breeding seasons and compensation for fishers adversely affected by the closures. Various law enforcement agencies enforce seasonal fishing ban periods generally from November to January and March to April-as well as imposing restrictions on the catch of juvenile hilsa ( $<25 \mathrm{~cm}$ in length) from November to June in five existing fish sanctuaries (encompassing approximately $7000 \mathrm{~km}^{2}$ ) in the Meghna river and estuary.

Furthermore, a comprehensive program has also been executed for the protection of the renewable natural resources ensuring the participation of all stakeholders including local public representatives, the Department of Fisheries, local administration, the Coast Guard, the Bangladesh Navy, fishers and the mass people living in the hilsa-rich river system. Hilsa fishers were provided with food-grains to live on and provisions to start alternative income-generating activities. As a result of these conservation measures, hilsa production increased from 0.199 million metric tons in 2003-2004 to 0.496 million metric tons in 2016-2017 [9].

Despite this management success of enhanced hilsa production, many dependent communities are still vulnerable to food insecurity and poverty, particularly during fishing ban seasons. Consequently, the sustainability of the hilsa restoration project is at risk through over-exploitation, non-compliance 
with regulations and conflicts over resource use. To avoid such a situation and to sustain the natural resilience of the hilsa fishery it is essential to enhance social resilience: the ability of individuals and communities to cope with disturbances and their means of adapting, transforming and potentially becoming stronger in the face of socio-economic, political and/or environmental challenges [18]. A healthy community is a prerequisite for a healthy ecosystem. In this regard, the establishment of co-management in the hilsa sanctuary areas could enhance both the social and natural resilience of hilsa fishery.

Co-management is one promising approach to sharing rights and responsibilities of resource use with local actors [19]. However, despite intensive attempts to implement co-management arrangements they often fail either to ensure environmental sustainability or social equity [20]. This paper attempts to contribute to an enhanced understanding of crucial issues to be considered as part of co-management approaches' efforts to facilitate sustainability and social resilience among hilsa fishers in Bangladesh. It aims to fill a gap in theoretical and empirical research regarding the social resilience of natural resource-dependent local communities and how the over-exploitation of natural resources relates to problems in social resilience. On this basis, we consider ways in which co-management systems could better reach their dual objectives of achieving sustainability in both social and ecological systems. Finally, by considering the hilsa fishery as a Social-Ecological System (SES), we aim to answer the following research questions:

(i) How has hilsa over-exploitation of natural resources undermined social resilience?

(ii) Can co-management enhance social resilience and if so, how?

Given that hilsa is a transboundary species, if good practices can be established in Bangladesh these can also serve as benchmarks for programs in other countries with similar contexts.

The sections of the paper are as follows: Section 2 gives an overview of the theoretical framework. Study areas and methodological considerations are stated in Section 3. Section 4 states our critical findings and then Section 5 relates these findings back to the theoretical framework and provides specific recommendations for practice and further research.

\section{Theoretical Framework}

As an analytical framework, this study draws on theories of Social-Ecological Systems (SES), social resilience, co-management. SES is a research paradigm that focuses on the interdependencies between human and environmental systems through links, synergies and feedbacks [21,22]. The integration of humans into natural systems is necessary because in any conservation effort there are interactions and feedback between ecological and social subsystems. These subsystems include vital links related to people's knowledge (local or traditional experience) and management institutions, as well as rules and norms that mediate how humans interact with the environment [23]. A growing body of literature supports the idea that small-scale fisheries can be understood as integrated SESs [24-26]. At the core of the SES approach to managing human-nature relations are the concept of resilience [27]. Resilience theory, with its origin in ecological integrity assessment [28], has evolved within a few social science-related fields, [5] including economics [29], anthropology [30], psychology [31], political ecology [32] and development studies [33]. Thus, in recent years, resilience has been taken up in interdisciplinary discourse concerning coupled human-environment systems, particularly about the natural environment and communities dependent thereon, where human and environmental nexuses are prevalent [18].

Social resilience is the ability of society (individuals, groups, communities) to cope with change, including shocks to their social infrastructure [18]. Ecological resilience is a well-established concept: the capability of an ecosystem or agro-ecosystem to tolerate and respond to biotic, abiotic and anthropogenic disturbances through adaptive responses [34]. In contrast, social resilience is a less-common term, though it has been used to explain disaster management [35], preventing degradation resulting from the over-exploitation of land in response to drought and other 
constraints [34], uncertainties in small-scale fishing [36], climate variability [37], commercial fishers' reactions to management [38] and resource dependencies [39]. However, there are inherent challenges in bringing together the 'social' and the 'ecological' and there is still a distinct knowledge gap concerning the social aspects of resilience [40,41].

One of the fundamental differences between social resilience and ecological resilience is that in social resilience the adaptive capacity in question relates to the ability of humans to influence their circumstances [42,43] intentionally. Thus, understanding social resilience calls for explicit attention to power relations and the unequal distribution of agency [40,43]. Furthermore, whether an individual or community can adapt to change (i.e., be resilient) depends on the degree of perceived risk involved in different types of change and uncertainty [44]. Overall, processes of politics, power and agency need to be integrated into social resilience to address issues of social justice, equity and human well-being [45]. Understanding how social resilience can be conceptualized and operationalized is an essential focus for research on the sustainability of SESs and resource-dependent communities [46]. Also, knowledge of the properties of social resilience can aid managers and resource users in designing policies that minimize adverse impacts on people and maximize the sustainability of the goods and services derived from the ecosystem [46].

Social resilience in an SES can be enhanced through co-management of the resources in question. Co-management can be a way of improving the social resilience of local communities, enabling them to have more power and control over decisions regarding how the natural resources they depend on are to be used [47]. Co-management refers to the sharing of management power and responsibility between government agencies and local people, typically through a formal agreement [48]. The co-management approach also considers issues of scale, such as administrative and geographic boundaries, institutions, rule systems (formal and informal), shared decision making and collective learning among actors that can help to develop more robust socio-ecological systems [49]. Some benefits of co-management include more participatory decision-making processes at the local level by engaging community members in the protection of their local resources and situating the rights and responsibilities of management with the people closest to the system, potentially increasing responsiveness to local needs [50].

Though in recent times research regarding socio-ecological resilience has grown progressively, the link between ecological and social resilience is not entirely clear [5]. However, it could be expected that a resilient ecosystem has the potential to support resilient communities and vice versa [51] but the interaction is not straightforward. For instance, social outcomes of resilient ecosystems are often mediated by several factors such as communities' resources, rights and access to the environment [7]. Similarly, ecosystem outcomes are dependent on social factors such as tenure within management regimes, markets, technological factors [52]. Examining this complex link between social and ecological resilience will require more in-depth consideration of social institutions (i.e., the formal and informal rules governing human behaviour) [53], as well as the roles of power and politics in enabling individuals, households and communities to benefit from ecological resilience [54].

\section{Research Site and Methods}

\subsection{Research Site}

Fieldwork to collect empirical data was conducted in two fishing villages-Rahmatpur and Sudirpur-located in the Andharmanik River hilsa sanctuary in the Kalapara Upazila sub-district of the Patuakhali district in southern Bangladesh (Figure 1). The geographic position of this area is $\left(21^{\circ} 52^{\prime} 24.01^{\prime \prime} \mathrm{N}-21^{\circ} 54^{\prime} 03.14^{\prime \prime} \mathrm{N}\right)$ and $\left(90^{\circ} 05^{\prime} 59.94^{\prime \prime} \mathrm{E}-90^{\circ} 06^{\prime} 57.84^{\prime \prime} \mathrm{E}\right)$ [55]. The Andharmanik River is one of the critical coastal rivers of the Ganges-Padma system of Bangladesh. It is a tidal river that originates with the Tiakhali River in the Barguna district and flows into the Bay of Bengal through the Patuakhali district. This river is well known as a breeding ground and nursery for hilsa. Considering the significance of the Andharmanik River, the government declared it as the 4th hilsa sanctuary 
and set a closure period for the juvenile catch (November to January) and for breeding female hilsa (October to November) [56]. The communities in question have relatively homogeneous populations and resource users share common interests where fishing is the dominant occupation. They depend on the hilsa sanctuaries for their livelihood from fishery-related activities such as fishing, fish drying, fish trading, net mending, boat making and boat repairing. Part-time fishers engage in other livelihood activities such as agriculture and day labour during the offseason months of fishing.

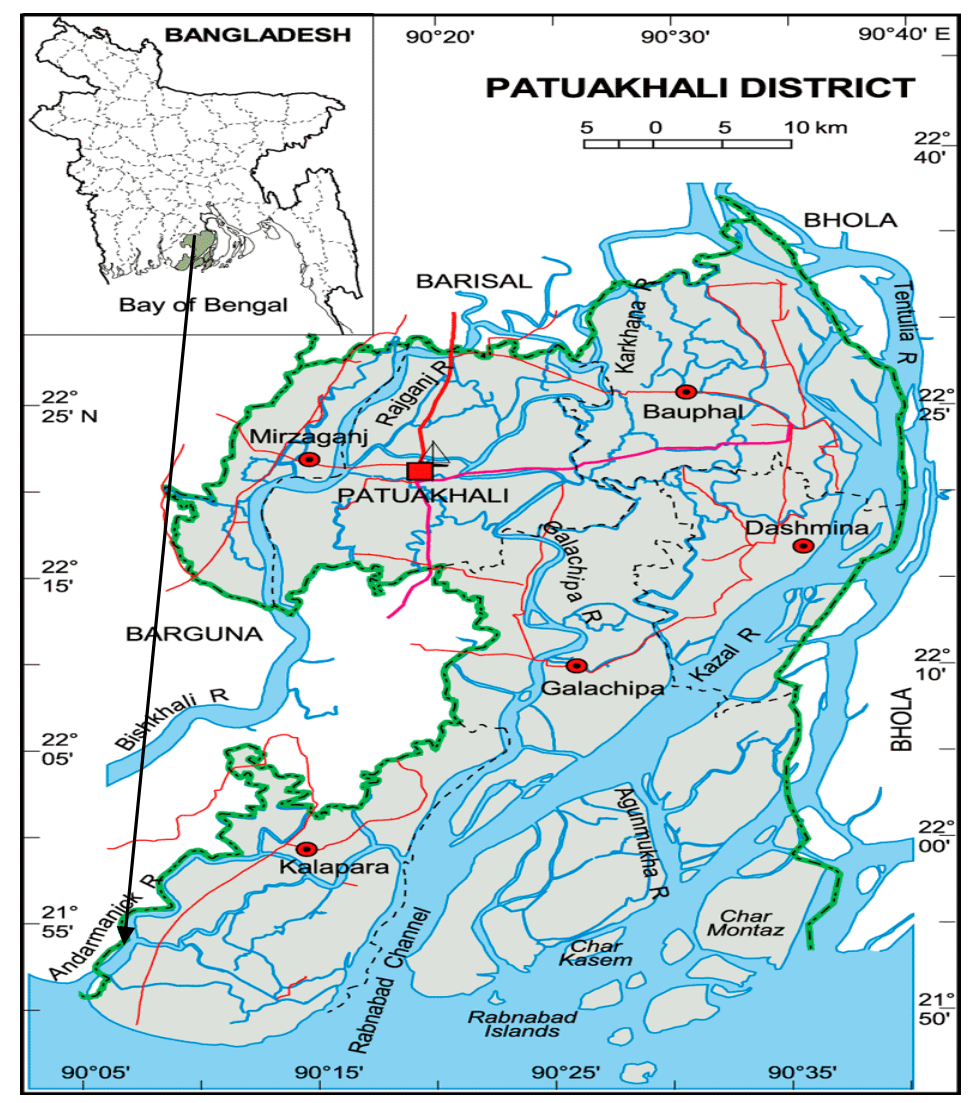

Figure 1. Location of study villages (Adopted from Ministry of Local Government, Rural Development and Cooperatives, Bangladesh) (http://www.lged.gov.bd/UploadedDocument/Map/BARISAL/ patuakhali/kalapara/kalapara.pdf.).

\subsection{Material and Methods}

For collecting our primary empirical data here, we utilized a set of qualitative tools, including semi-structured individual and focus group interviews. The qualitative method enables the exploration of a phenomenon within its context from a broad range of perspectives, thus preventing the phenomenon from being seen only through one lens; providing a range of lenses which allow for multiple sides of the phenomenon to be revealed and understood [57]. Furthermore, within a qualitative method, all data are symbolic representations which need to be interpreted; their meaning is subjective and context dependent [58]. Beyond that, we chose to follow a qualitative methodology here because it enabled us to consider our interviewees' various areas of expertise more flexibly. In-depth individual interviews provided us with an understanding of details regarding each interviewee's perspectives on their lives, experiences or situations as expressed in their own words; focus group discussions, with insights into matters of local consensus and diversity of viewpoints [59-61].

Using a "snowballing" sampling method within these small communities, we were able to contact a wide variety of actors in the local fishery economy. Our sample included both men and women to consider gendered differences in perception [62]. A total of 60 in-depth individual interviews (30 interviews in each village) and two focus group discussions (one in each village) were carried out from 
December 2016-February 2017 (Table 1). The sample distributions for the in-depth interviews were as follows:

Table 1. Sample distributions of In-depth interviews.

\begin{tabular}{ccc}
\hline Participants/Stakeholder Groups & $\begin{array}{c}\text { Number of Participants in } \\
\text { Rahmatpur (Village 1) }\end{array}$ & $\begin{array}{c}\text { Number of Participants in } \\
\text { Sudirpur (Village 2) }\end{array}$ \\
\hline Hilsa fishers & Man-15 & Man-15 \\
Boat owners & Woman-5 & Woman-5 \\
Fish traders & 1 & 1 \\
Money Lenders & 1 & 1 \\
Local NGOs representatives & 2 & 2 \\
Local government representatives (Upazila & 2 & 2 \\
Chairman, Union Parishad Chairman) & 2 & 2 \\
Local governments administrative \\
personnel's (Fishery officer, Police)
\end{tabular}

The concept of saturation was the core guiding principle to determine sample sizes in this study [63]. Interviews were semi-structured but allowed for continuing talks. At the beginning of the discussion, the concept of social resilience was presented to the interviewees (mainly hilsa fishers) including its basic definition, essential factors in building social resilience individually and communally and existing and potential public programs to enhance the social resilience of communities. Also, a list of discussion topics focused the talks on the livelihood of fishing communities, socio-economic consequences of a reduced hilsa catch, their strategies to cope with such socio-economic difficulties and the role of local ecological knowledge in fishery management.

Furthermore, the participants' perceptions regarding the enhancement of social resilience as a form of ability to cope with disturbances and how they adapt, transform and potentially become stronger via co-management efforts, were also discussed (see the supplementary file). The same questions were not asked of each participant and the interview questions were different for different stakeholders (see the supplementary file). Individual interviews lasted $60-80 \mathrm{~min}$ on average and by prior consent were audio-recorded.

Our focus group discussions each involved 10 participants (4 hilsa fishers, both male and female and one representative of each additional stakeholder group). Each focus group discussion was lasted 40-50 min (Table 2).

Table 2. Sample distribution of Focus group discussions.

\begin{tabular}{ccc}
\hline Participants/Stakeholder Groups & $\begin{array}{c}\text { Number of Participants in } \\
\text { Rahmatpur (Village 1) }\end{array}$ & $\begin{array}{c}\text { Number of Participants in } \\
\text { Sudirpur (Village 2) }\end{array}$ \\
\hline Hilsa fishers & Man-2 & Man-2 \\
Boat owners & Woman-2 & 1 \\
Fish traders & 1 & 1 \\
Money Lenders & 1 & 1 \\
Local NGOs representatives & 1 & 1 \\
Local government representatives (Upazila & 1 & 1 \\
Chairman, Union Parishad Chairman) \\
$\begin{array}{c}\text { Local governments administrative } \\
\text { personnel's (Fishery officer, Police) }\end{array}$ & 1 & 1 \\
\hline
\end{tabular}

The use of various sources of evidence was critical to developing converging lines of inquiry (i.e., triangulation), to support the research findings, or at least to coincide with them suitably [64]. Interview questions and themes discussed in focus groups were informed by the SES, social resilience and co-management framework $[19,22,36]$.

Secondary data has been collected regarding aspects of the situation and events that were not sufficiently addressed in the primary data. Sources of secondary data here include publications from 
local NGOs working with coastal fishers or related projects, reports published by Ministry of Fisheries, newspaper reports and from various internet resources.

The content analysis method was used for data analyses [65]. This process is helpful for interpreting and coding textual material (e.g., documents, books, oral communication, interviews and graphics) to elicit meaningful information over different themes. More specifically, in this study, we used the inductive approach of content analysis to answer the question of what the fundamental problems were local that co-management could solve and what the underlying issues were that co-management approaches should consider [66]. Importantly, this method is suitable for developing a theory or new categories under established ones. More specifically, in this study, we used the inductive approach of content analysis to answer the question on what the fundamental problems were for local social resilience and what underlying issues that co-management approaches should consider enhancing social resilience [66]. Inductive method is suitable for developing a theory or new categories under established ones. The steps for the inductive approach of content analysis were as follows (Figure 2): Preparation phase and organizing phase.

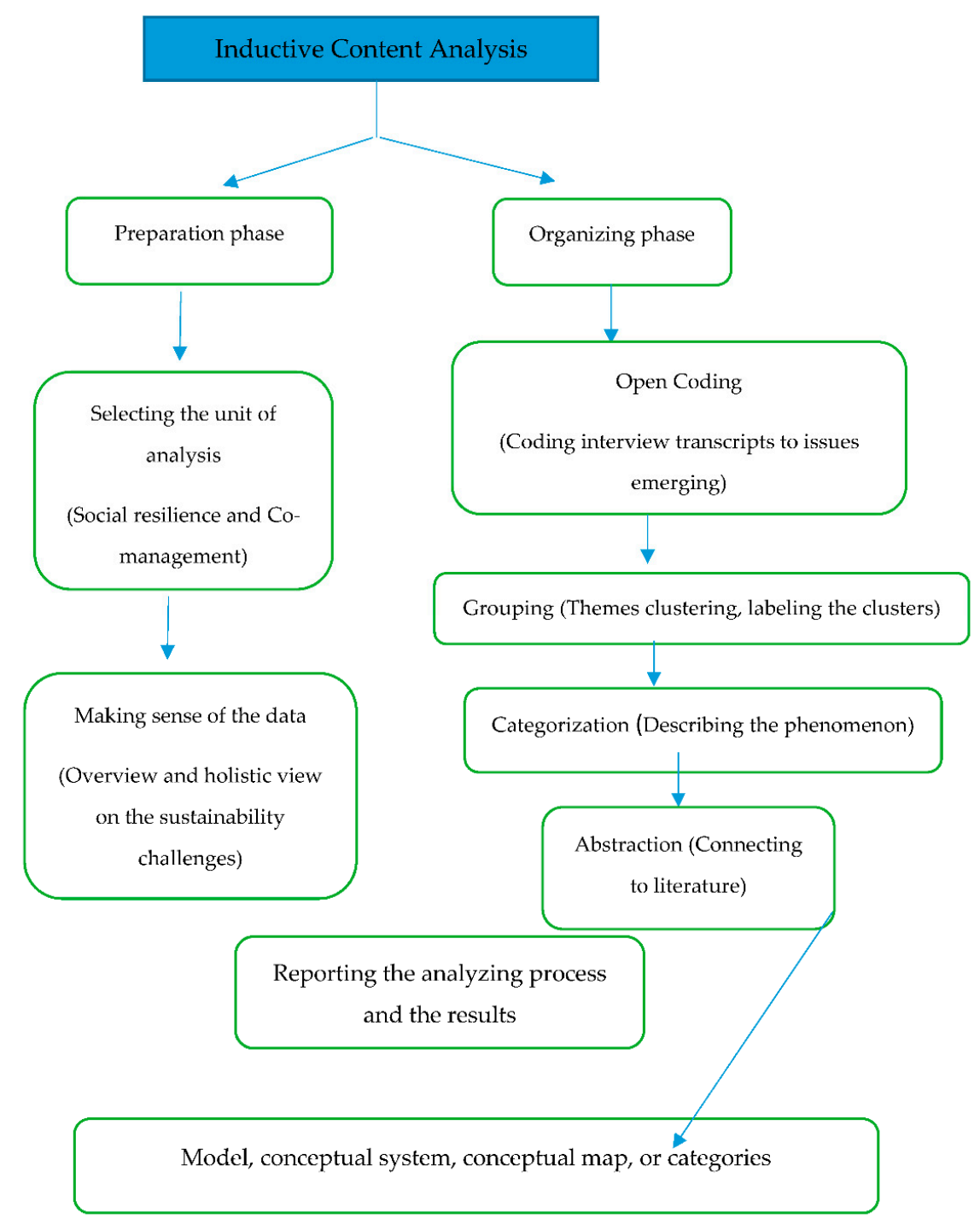

Figure 2. Adopted Inductive Content Analysis diagram [66].

Preparation phase included selecting the unit of analysis (social resilience and co-management) and made sense of the data (overview and holistic view on the sustainability challenges). During the preparation phase, all the recorded interviews were first transcribed in Bengali and then translated 
into English. In the organizing phase, the steps included open coding (coding interview transcripts to issues emerging), grouping (themes clustering, labelling the clusters), categorization (describing the central phenomenon) and abstraction. Abstraction means formulating a general description of the research topic through generating categories [67]. The abstraction process continues as far as was reasonable and possible.

We clustered interview material according to problems and proposals that co-management should consider. As a result of inductive content analysis following groups were formed: (i) socio-economic impacts on fishers in the communities: food security, employment, poverty, migration, dependency on easy credit (debt cycle) and social tensions; and (ii) efforts to enhance social resilience: alternative livelihood options, developing community infrastructures, building community networks, updating existing rules and regulations, use of local ecological knowledge, sharing responsibilities and micro-credit facilities. From there, we connected the proposals for co-management arising within our primary data with existing literature in the field, enabling us to discuss some little-examined issues regarding co-management. We illustrate the key findings from our empirical material with direct quotations which exemplify the categories into which portions of the interview transcripts were clustered. No qualitative data analysis software was used, instead of a manual procedure was used in this study.

\section{Results}

\subsection{Socio-Economic Profiles}

This section describes the socio-economic profiles (Table 3) of the fishers interviewed and the different drivers that regulate their social well-being. To assess the social resilience of the fisher communities, it is essential to understand their socio-economic conditions. Since socio-economic conditions determine the adaptive capacity of the communities, the socio-economic profile of a community should be a good indicator of community resilience.

Most of the respondents were above 30 years age. Thus, their opinions should reflect a fair amount of experience and maturity. Most of the fishers interviewed qualify as very poor concerning income: $37 \%$ earned less 5000 BDT per month and only $20 \%$ were above the official poverty line of 10,000 BDT per month. Furthermore, nearly half of the fishers interviewed had more than five family members depending on their single income. Their access to socio-economic assets also limited. Most of the fishers live in simple thatched houses. Only $37 \%$ had access to safe drinking water and $40 \%$ had access to sanitation facilities. Only $25 \%$ had electricity in their homes. Furthermore, the nearest health centre is $10 \mathrm{~km}$ away from the areas studied and there was no cyclone shelter in either village, although the area is classified as cyclone prone.

Most of the respondents did not have their boat or fishing equipment: $37 \%$ worked as labourers on other people's boats and $43 \%$ rent boats and equipment to fish as entrepreneurs. Most of the respondents $(60 \%)$ have insufficient leisure time, working 21-30 days per month. As a negative coping strategy about $75 \%$ uses illegal monofilament gillnets. Over two-thirds (70\%) of the fishers interviewed are illiterate; $17 \%$ had attended primary school up to fifth grade and only $5 \%$ had completed their secondary education. This widespread illiteracy could be primary driver for their poverty, as it is a significant barrier to enhancing their position in working life. One interviewee also revealed that the nearest school was over $2 \mathrm{~km}$ away and it was inaccessible due to lack of proper road connections. Child labour is thus quite common among fishers. Fisher parents are unable to send their children to school due to the lost working hours in fishing that this would create. However, fishers wanted to educate their children that will increase the chance to get a decent job in the future.

During the focus group discussions, when asked to summarize their feelings (both negative and positive) about the socioeconomic implications of hilsa sanctuaries, fishers tended to focus on how these have negatively affected their income and the security of their household food consumption 
and led to increased conflicts among fishers. To compensate for the loss of fishing income during the banned season, they mainly worked in agriculture, as day labourers.

Table 3. Socioeconomic and demographic condition of the respondent fishers $(\mathrm{N}=40)$.

\begin{tabular}{|c|c|}
\hline Socioeconomic Characteristics & Percentage $(\%)$ \\
\hline \multicolumn{2}{|l|}{ Age (years) } \\
\hline$<30$ & 12.5 \\
\hline $31-35$ & 32.5 \\
\hline $36-40$ & 30 \\
\hline$>41$ & 25 \\
\hline \multicolumn{2}{|l|}{ Family size (members) } \\
\hline $1-2$ & 27.5 \\
\hline $3-4$ & 25 \\
\hline$>5$ & 47.5 \\
\hline \multicolumn{2}{|l|}{ Educational status } \\
\hline No education (illiterate and can sign only) & 70 \\
\hline Five years of schooling & 17.5 \\
\hline Eight years of schooling & 7.5 \\
\hline Ten years of schooling & 5 \\
\hline \multicolumn{2}{|l|}{ Housing condition } \\
\hline Cane/palm/trunks & 47.5 \\
\hline Corrugated iron & 32.5 \\
\hline Cement \& brick & 5 \\
\hline Wood planks \& shingles & 15 \\
\hline \multicolumn{2}{|l|}{ Households' ownership of assets } \\
\hline Television & 20 \\
\hline Radio & 37.5 \\
\hline Mobile Phone & 87.5 \\
\hline Access to electricity & 25 \\
\hline Access to safe drinking water & 37.5 \\
\hline Access to sanitary toilet & 40 \\
\hline \multicolumn{2}{|l|}{ Fishing operations } \\
\hline Own boat and net & 20 \\
\hline Hired boat and net & 42.5 \\
\hline Labour & 37.5 \\
\hline Use of monofilament gillnet (current jal) & 75 \\
\hline \multicolumn{2}{|l|}{ Monthly income in Bangladeshi Taka (BDT) } \\
\hline$\leq 5000$ & 37.5 \\
\hline $5000-10,000$ & 42.5 \\
\hline $10,000-20,000$ & 20 \\
\hline \multicolumn{2}{|l|}{ Working days per month } \\
\hline$<15$ & 12.5 \\
\hline $16-20$ & 27.5 \\
\hline $21-30$ & 60 \\
\hline \multicolumn{2}{|l|}{ Supplementary occupation } \\
\hline Agriculture & 45 \\
\hline Firewood collection & 7.5 \\
\hline Day labour & 17.5 \\
\hline Boat making & 17.5 \\
\hline
\end{tabular}

\subsection{Challenges to Social Resilience}

\subsubsection{Food Security}

Most of the respondents raised concerns about year-round food insecurity. They reported food insecurity particularly during the banned fishing period in the sanctuary. Though the government has rolled out an incentive program providing $40 \mathrm{~kg}$ of rice per month during the time of the 
fishery closures, fishers complained that the incentives almost never come in time to feed their families during the fishing ban period. Also, not all fishers were included on the beneficiary lists. Some indicated mismanagement and official corruption among local government officials in the preparation of beneficiary lists: some deserving fishers were excluded from these lists and some non-fishers were given benefits intended as incentives not to fish during the ban periods through nepotism. Respondents in both study areas had complained of such irregularities. Competition for inclusion in the government compensation scheme, together with irregularities in its distribution, sometimes caused a spike in tension. Also, it was discussed in the focus group discussion that sometimes incentives were distributed after the ban period due to complicated bureaucratic processes. Hilsa fishers said that this program did not help them at all and thus they had to resort to illegal fishing or to taking loans from the dadondars (money lenders). Also, during the rest of the period, they faced erratic hilsa catches, negatively affecting their food security. A respondent from Rahmatpur explained:

"We have been catching hilsa for years. So did my parents. In those days, the fish were large, and we found plenty. These days there is less fish and they are getting smaller. Now, this fish is becoming very rare and the price of hilsa is going up gradually. Today three of us went out together and only caught eight hilsa. If we eat those fish, we cannot pay the rent for the boat and the fishing gear and cost of fuel. We will sell the fish and buy rice and vegetables to feed our families. We will eat hilsa when there is huge hilsa catch in our net. Also, we are poor and do not have much access to other high nutrient foods. Thus, our family members and we get a lack of essential nutrients in our bodies that causes many health problems."

\subsubsection{Poverty and Debt Cycle}

Most of the respondents considered their income from fishing to be poor. Some fishers reported that hilsa fishing is very capital intensive. To buy fishing boats and gear requires taking out a loan from unofficial lenders: dadondars. One key point discussed in focus groups was the fishers' lack of access to the formal credit markets (i.e., banks), due to a lack of, or insufficient, collateral for a loan, such as landed property. Thus, they remain dependent on informal credit mechanisms, like the dadon system. A dadon is a deal built based on an unwritten contract between the fisher and the money lender-whereby the lender requires that the fisher sell the fish to him, or he gets a specific commission when fish is sold to a third person. Thus, the dadon system binds the fishers to the money lender in a debt cycle. This casual arrangement was often blamed for exploiting the fishers. Therefore, though sometimes they had a good catch, after meeting all expenses they had very little to live on. Excessive pressure to pay loans bound them to engage in illegal fishing in sanctuaries during the ban period. Fishers from Sudirpur stated:

"There are lots of hilsa fishers in the locality nowadays and the catch is less. Also, we take a loan from the dadondars to buy boats, fishing gear and to survive during the crisis period. Hence, we must sell the fish to the local money lenders and price is fixed by them. We did not get the actual price of the fish. Sometimes we even did not earn the expenditure that was spent on the whole fishing trip due to less hilsa in the river. Our living standard did not change at all. We remain poor all year round."

\subsubsection{Employment and Migration}

Banned seasons in the sanctuary and occasional erratic catches also caused seasonal unemployment. Respondents from Rahmatpur added that such impacts included a freeze on development in fishing villages and in some cases, the gradual deterioration of existing facilities and traditional social support systems for the aged, as many young men left their communities to seek employment in nearby cities. Also, in the absence of gainful employment, many turned to crime and social unrest to express their frustration and loss of hope in future. Some fishers have embarked on illegal migration to Malaysia or other neighbouring countries, either by paying human traffickers or using fishing boats. 


\subsubsection{Social Tensions}

There is intense competition for fishing space in the sanctuary which often leads to conflicts when different fishers try to spread nets close to one another. Such a situation, in turn, leads to a loss of property or even physical harm, often spilling over into other communities, further increasing social tensions on land. Remarkably, these conflicts were frequently delineated as between mechanized and non-mechanized fishers. Fishers with non-mechanized boats (rowboats, without an engine) and those with mechanized boats blamed each other for illegal fishing, though both types of fishers continue fishing during the banned period. Due to their limited manoeuvrability in their smaller boats, non-mechanized fishers could only harvest a smaller catch of illegal fish and they were often caught red-handed during raids by law enforcement officials (Police, Coastguard). Mechanized fishers, on the other hand, could catch more fish illegally and escaped with them more easily thanks to the higher speed and manoeuvrability of their boats. One fisher from Sudirpur explained:

"Large mechanized boats are owned by the local elite, who typically give bribes to the police and can continue fishing at night during the banned seasons. If there is any raid, they usually find out about it in advance from their sources in the police station."

Most of the respondents perceived that establishment of sanctuaries had helped the coastal ecosystem in the long term (more variety of fish species including hilsa), however adding new sanctuaries can lead to conflicts.

\subsection{Community Perceptions of How to Enhance the Social Resilience of the Fishers}

\subsubsection{Alternative Livelihood Options}

To compensate for the loss of income during the banned period, the government also provided support for alternative occupations for the affected fishers. These supports, however, were insufficient and participants of the focus group discussions said that the alternative income generating opportunities of the hilsa fisher communities were very limited. These limitations related to the lack of diversity in these isolated local economies, the fishers' lack of other skills and their lack of start-up capital for other types of ventures. In such a situation, the respondents suggested that greater support for alternative livelihood options was necessary to enhance the resilience of fishing communities in the region. They said that such opportunities would help to support the implementation of the hilsa conservation measures during the banned period. Our focus group discussions also identified some viable alternative livelihood options for the fishers and their family members. These included nets making, cage culture/fish farming, poultry rearing (ducks and chickens), small dairy ventures (keeping goats or cows and selling milk or meat), plant nurseries, gardening and handicrafts (doll making). A few fisherwomen were already involved in alternative livelihood options and they felt that they could play a stronger indirect role in conserving hilsa by supplementing their family incomes by other means. Thus, giving them a stronger voice in the co-management of fisheries improve household and community resilience. A female respondent from Rahmatpur said:

"We know fishing ban periods are good for the growth and abundance of hilsa. However, during the fishing ban period, my husband cannot go fishing and cannot buy food for us. It is a critical time to survive. Sometimes, we do not get incentives properly. To escape from this hardship, my husband fishes illegally. The existing initiatives as a form of alternative income generating is a good step for the fishers. Perhaps we can survive during the lean period by selling the handicraft products (dolls) in the local market."

\subsubsection{Investment in Building Community Infrastructures}

Very weak infrastructure development in general characterizes the sites where we conducted our interviews. The region is subject to tidal surges and cyclones that frequently destroy local infrastructure 
and standing crops, as well as causing human causalities. The poor remaining infrastructure has direct implications for the livelihoods of the fishers. One fisher from Sudirpur said:

"We do not have electricity and we do not have any cold storage facility within $35 \mathrm{~km}$ of this area. The nearest market is far away from here and it is expensive to try to transport our catch to other districts. We must sell the fish to the local agents and they fix the price. So we do not get a fair price for the fish. If the government would take the initiative to set up cold storage facilities and construct roads, we could sell the fish at a higher price and lead a decent life."

\subsubsection{Building Community Networks}

Nurturing strong mutual support networks within local communities could significantly enhance their social resilience. In the case of looking for solutions to problems related to ecological changes and consequent changes in their profession, hilsa fishers tend to discuss such matters with family members, neighbours, their local chief, wise village elders, friends and NGO officers, all of which ultimately enable the hilsa fishers to form community networks. Also, while crises and other changes lead them to draw on existing community networks for support, fishers also help in network building by providing a specific focus for individuals and groups for working together on, to overcome the crises at hand. Fishers identified these networks' direct efforts in activities such as forming a volunteer community fish guard to protect hilsa during the ban period, organizing celebrations (Bengali New Year, religious festivals, marriage ceremonies) and building a co-operative bank to support those in need.

\subsubsection{Improvement of the Legal Framework through Community Consultation}

The government of Bangladesh has passed several acts, ordinances and rules to provide a framework for the exploitation, development, management and conservation of its fisheries sector and aquatic resources. However, hilsa fishers are rarely consulted before changes are made in fishery regulations. Such conditions contribute to the elevated rates of non-compliance with such ordinances and the ensuing conflicts and was evident during our focus group discussions. One fisher from Sudirpur stated:

"We are aware of different laws and punishments such as seizing our hilsa catch, monetary fines and imprisonment. However, there is a necessity to update the rules and regulations. As an example, there is a law to seize jal nets (monofilament gill nets with a mesh size of less than $6 \mathrm{~cm}$ ) from fishers while fishing. However, there is no law or regulations to stop the production or selling of jal nets in the market."

Through non-compliance, many fishers face legal penalties and thus increased poverty and vulnerability.

\subsubsection{Use of Local Ecological Knowledge}

It was apparent in the interviews and focus group discussions that local and particularly elderly hilsa fishers were excellent sources of local ecological knowledge about the fishery resources, fish movements, seasonal fluctuations in fish stocks, details of their reproductive and feeding behaviours, feeding grounds and other environmental factors. Fishers stressed that local fisheries department officials should discuss such matters with the old and experienced hilsa fishers and use such local knowledge in setting the dates for fishing bans and the geographical boundaries for fish sanctuaries and in formulating other such fishery policies.

\subsubsection{Sharing Responsibilities}

Fishers and other stakeholders suggested sharing responsibilities (control and surveillance, responsible harvesting, incentive distribution and result-monitoring) between the government and the stakeholders to manage the hilsa fishery sustainably and enhance the resilience of the fishing 
community. In doing so, stakeholders identified the possible benefits of sharing responsibilities and discussed the potential sharing arrangements. The respondents agreed that a central task of the community as such is to set up a system of rights and rules that are culturally and socially appropriate and contribute to sustainable management. One of the fishers from Rahmatpur stated the rationale behind community participation in management processes as follows:

"Hilsa is everything for us. We cannot think a single day without hilsa. Our livelihood, culture and customs all relate to hilsa. If there is no hilsa in the rivers, we must suffer in the long run. For our betterment, we must take part in the government program for the sustainable management of the hilsa. However, fishery department officials should work with us, not just sit in their offices all the time."

\subsubsection{Micro-Credit Facilities}

Most of the hilsa fishers lack the means to operate in this profession without outside capital. Thus, to continue fishing, they must seek credit either from NGOs or the local dadondars with their restrictive terms and high-interest rates. One fisher from Rahmatpur made the following appeal:

"We could not get a loan from the government or the non-government commercial bank as we do not have property. We want to get away from the local dadondars. The government of Bangladesh should take the initiative to introduce a soft loan or micro-insurance for hilsa fishers so that we can have the initial capital to procure nets, boats and other fishing materials. Such an initiative will eventually reduce the negative influence of dadondars and we will not have to sell our catch to the dadondars at the minimum price."

A summary of the presented results was shown in Table 4.

Table 4. Challenges to social resilience and fishers' suggestions for addressing them.

\begin{tabular}{cll}
\hline Challenge for Social Resilience & Empirical Description of the Challenge & What Can Be Done to Address the Problem \\
\hline Food security & $\begin{array}{l}\text { Banned seasons for hilsa fishing and } \\
\text { insufficient and untimely distribution of } \\
\text { rice incentives cause seasonal food } \\
\text { insecurity for the hilsa fishers. }\end{array}$ & $\begin{array}{l}\text { Alternative livelihood options, sharing } \\
\text { responsibilities with the government, use of } \\
\text { local ecological knowledge, fishing other fish } \\
\text { species and improving fishing rules and } \\
\text { regulations through community consultation. }\end{array}$ \\
\hline Poverty and debt cycle & $\begin{array}{l}\text { Fisher's access to the formal credit } \\
\text { markets is limited. Fishers depended on } \\
\text { the informal credit (dadon) system to buy } \\
\text { fishing gear and boats. This system } \\
\text { requires fishers to sell their catch directly } \\
\text { to their creditors and thus prevents them } \\
\text { from getting a fair price for the fish. }\end{array}$ & $\begin{array}{l}\text { Alternative livelihood options, building } \\
\text { community networks (co-operative bank) and } \\
\text { the introduction of micro-credit facilities. }\end{array}$ \\
\hline Employment and migration & $\begin{array}{l}\text { Due to reduced catches, several fishers } \\
\text { depending on hilsa fisheries as a source of } \\
\text { livelihood have become unemployed and } \\
\text { migrated to nearby cities. }\end{array}$ & $\begin{array}{l}\text { Alternative local livelihood options, } \\
\text { developing community infrastructures and } \\
\text { community networks. }\end{array}$ \\
\hline $\begin{array}{l}\text { Illegal fishing (from mechanized and } \\
\text { non-mechanized boats), the pressure to } \\
\text { fish illegally to pay off loans from } \\
\text { dadondars having negative impacts on } \\
\text { hilsa sanctuaries; unfair incentive } \\
\text { distribution practices. }\end{array}$ & $\begin{array}{l}\text { Sharing responsibilities as a form of } \\
\text { co-management, use of local ecological } \\
\text { knowledge and opportunities for micro-credit } \\
\text { facilities. }\end{array}$ \\
\hline
\end{tabular}

\section{Discussion}

To achieve resilient co-management systems, two types of responses are to be considered: coping mechanisms and adaptive strategies. Coping mechanisms are short-term emergency responses to abnormal seasons or years; adaptive strategies are ways in which individuals, households and communities change their systems of production and modify local rules and institutional structures to secure livelihoods [68]. Co-management works best if the local community focuses on formulating a system of rights and regulations, while the government focuses on formulating a legal framework to 
back up the system [50]. The social resilience of the local fishery-based communities can be restored through co-management with the involvement of different stakeholders.

\subsection{Governance Responses (Incentives and Institutional Arrangements)}

While fishery sanctuaries are a useful management tool, they can also negatively affect dependent communities socially, economically, culturally and politically $[69,70]$. Though fishers perceived the positive ecological impacts of sanctuary establishment, as they rely on the fishery for their livelihoods, their self-interested behaviour is often contrary to conservation goals. Fishers who belong to an organization such as a cooperative, however, are more inclined to consider the establishment of sanctuaries as a positive move by the government. Such an attitude is related to the fact that members of social organizations may be outspoken and involved in management. Thus, they receive relevant knowledge and feedback on sanctuaries and find the opportunity for social interactions with other stakeholders. The inclusion of fishers in local social organizations as a means of co-management through government support will, therefore, be helpful in making conservation efforts successful. It is thus to be recommended that local people, including fishers, would be enabled to participate more in co-management to increase the legitimacy of conservation efforts from their perspectives, thereby enabling better socioeconomic and ecological outcomes [71]. The success of conservation measures is highly dependent on delegating responsibilities to communities [72,73]. This type of restructuring can produce multiple benefits for the existing hilsa sanctuary management system. Firstly, as hilsa sanctuaries exist in high population density basins, resident fishers can easily watch/patrol these areas. Secondly, if fishers and other stakeholders in the value chain, such as fish traders and money lenders are to shoulder some responsibility for managing sanctuaries, they are less likely to encourage the violation of the conservation regulations. For these reasons, the engagement of all stakeholders in monitoring and policing activities should be considered, along with a compensation scheme for those doing so. Also, to make the sanctuaries more successful, various social welfare and local level social development programmes should aim to create new economic opportunities for fishers and their families.

The incentive-based hilsa conservation programme has three primary functions: raising awareness of sustainability issues, providing supplementary food to fisher households as an incentive for cooperation and supporting alternative income-generating activities [10]. As observed in the present study, the incentive distribution is not equitable enough, as non-fishers also get incentives and the amount of incentives is not adequate to keep families fed. It is often the case that small-scale fishers are disproportionately negatively affected in the short term by limits on their harvests, due to a massive reliance on fishing and limited alternative livelihood options [74]. Hence, schemes need to make a carefully assess 'who loses and who wins' and estimate as accurately as possible any loss of earnings arising from measures restricting access to resources [75].

Fishery management regulations cannot be successful without support from the fishers because otherwise fishers will very often break the rules and make the management of fisheries more expensive [76]. The government uses a top-down management system in many small-scale fisheries with little or no participation by fisher groups [77]. The intentional transformation of governance institutions may be a necessary step toward the longer-term goal of resilient livelihoods. This will require a shift away from the current top-down model toward one of adaptive governance-utilizing a range of interactions between actors, networks, organizations and institutions emerging in pursuit of the predetermined sustainable condition for social-ecological systems [78].

\subsection{Opportunities for Diversified Incomes}

Alternative livelihoods can be of help, by encouraging fisher's dependent on fishery resources to move away from unsustainable harvesting practices, as well as directly alleviating some of the poverty in fishery regions $[79,80]$. Fishers are found to be unable to depend on their primary occupation related to hilsa fishing as their sole source of income. Alternative livelihood options can be arranged for the 
fishers during lean periods and times when fishing is banned for purposes of conservation. Studies on employment, labour, productivity and income in small-scale fisheries have found that coastal fishers in Bangladesh have the lowest level of education within this profession [81]. Our findings support this conclusion and this factor also creates a barrier to their finding alternative decent jobs in their locality. Fishing households with financial assets and liquid capital at their disposal have taken up intensification and diversification of their fishery activities as alternative livelihood strategies, adding to the problems of more impoverished families by further degrading the fishery resources. Consequently, poorer fisher households have either opted for a coping approach (loans, mortgages, asset liquidation, changing food habits) or labour migration in search of alternative livelihoods [26].

\subsection{Financial Assistance}

Informal credit (dadon) from a fish entrepreneur (aratdar) is the only source of financing currently available to poorer hilsa fishers, as their business is very capital-intensive and most lack the collateral necessary to facilitate a loan from a regular commercial bank [56]. They also tend to fear the awkward and lengthy processes of applying for institutional credit. From there excessive pressure to pay off their informal loans from the dadondars compels many marginal fishers to engage in illegal and unsustainable fishing practices. Natural term institutional credit facilities at low-interest rates without a requirement of collateral is particularly needed among Hilsa fishers. Microcredit can be an essential tool in this regard. By extending small, collateral-free institutional loans to members of a jointly-liable group of poor workers for purposes of enabling self-employment and income-generating activities [82-84], microcredit helps diversify livelihoods of the people who are entirely or partially dependent on shared pool resources for their livelihoods.

\subsection{Participation and Local Knowledge}

Fishery management requires the implementation of such measures as monitoring, control and surveillance (MCS) of closed areas during closed seasons. Without the involvement of communities, it is impossible to effectively implement these measures to protect fishery resources $[85,86]$. In our study, hilsa fishers and other stakeholders also stated their positive orientation toward participating in the co-management process to improve the sustainability of the hilsa fishery and enhance their social resilience.

Small-scale coastal fishers observe the local marine environment constantly when fishing and hence are attuned to changes in the abundance or catchability of targeted species [87]. Local fishers are often the first to notice changes in species' abundance [88]. Thus, there have been recommendations to integrate local and traditional knowledge into fisheries' management and conservation programs [88,89]. Traditional and local experience has led to the "discovery" of ecological or behavioural phenomena previously unknown to scientists. For example, indigenous peoples in the Western Solomon Islands pinpointed population changes of Bump head parrotfish (Bolbometopon muricatumand) and provided useful conservation strategies for its protection [90]. Different case studies have shown that local knowledge has a vital role to play in the better management of Bangladesh's inland and coastal fisheries, as does sharing of experience among communities [91-93]. Communities can agree on and implement actions to improve fishery management but in the long term, this requires a framework of government support for local community initiatives when they are being threatened by local elite interests [94]. The present study also reveals that hilsa fishers have immense local knowledge concerning hilsa's breeding periods, feeding habits, fishing ground and migration patterns, and such knowledge should be included in the co-management process.

\section{Conclusions}

Hilsa constitute the most important coastal and marine fishery in Bangladesh. Considering the economic, social and cultural values of this fishery, the government has taken several initiatives that include the establishment of five sanctuaries in the Padma-Meghna River habitats. These initiatives 
certainly enhanced the ecological resilience of the hilsa fishery system, but they also have some negative implications for the social resilience of hilsa-dependent communities. Due to fishery closures and fluctuating catches from hilsa fisheries in the sanctuary areas, hilsa fishers are facing many social consequences and they are becoming less socially resilient. Innovative, dispersed and participatory co-management solutions are thus needed to build sustainable fisheries and to cope with the various social problems in these regions. It could be anticipated that if managed efficiently, increased hilsa production would boost fishers' resilience regarding their subsistence-based livelihoods, including their social identities and cultural experiences. Considering the above hilsa fishery scenarios, we suggest that enhancing the social resilience of fishing communities through co-management will require the following initiatives:

(i) Investments in community-level infrastructure should be made urgently in coastal fishing communities, leading to greater wealth creation and reduced vulnerability.

(ii) As fisheries are complex SESs, fishers' traditional knowledge, experience, observations and opinions should be incorporated into fishery management policies and the implementation of those policies.

(iii) Fishers must be provided with adequate compensation for their financial losses, enabling them to meet their basic subsistence needs, during periods when fishing must be temporarily banned.

(iv) Arrangements should be made to provide alternative livelihood possibilities for fishers through need-based training, vocational refresher courses and microcredit, to keep them from feeling that illegal fishing is the only productive activity available to them.

(v) The economic empowerment of women within fisher households-through forms of employment ranging from handicrafts to poultry keeping, to net making, enabled by either governmental or non-governmental organizational activities-must be considered as part of the overall pattern of social resilience within the community.

(vi) Natural term institutional credit at low-interest rates without a requirement of collateral should be introduced for the benefit of hilsa fishers, together with community supported fish marketing schemes (CFMs), to free the fishers from reliance on the dadondar so that poor hilsa fishers can buy boats and equipment in advance and then get more of a fair market price for their catch.

(vii) There are many groups and categories of people involved in the hilsa value chain. It is essential to find out whether other key stakeholders in the hilsa fishing industry (rental boat owners, dadondar, fish merchants) support the principle of biodiversity conservation. By controlling the means of production needed by the fishers, they control much of the fishing operations in the sanctuary areas, including the extent to which fishers must operate illegally to continue with that form of livelihood. The government must then take these key stakeholders as well into consideration when designing incentive and compensation schemes. However, further empirical research is necessary regarding how to both integrate them into the compensation scheme and free the hilsa fishers from their control.

(viii) Finally, a set of social resilience characteristics that are essential and common across fishing community contexts globally need to be identified to develop a generic social resilience framework. However, further investigation is necessary to create such a generic framework. We have attempted to lay some basic foundations for such a project by pinpointing key issues underpinning social resilience beyond a simple focus on rules of environmental management usually at the foci of co-management literature.

Supplementary Materials: The following are available online at http:/ / www.mdpi.com/2071-1050/10/10/3501/ s1.

Author Contributions: This article is based on first author's Ph.D. studies. M.M.H.M. design the research, developed the questionnaire, collected data, analysed data, compiled the draft and finally revised and checked the manuscript. A.W. supervised, read and edited the manuscript. P.S. supervised, read and revised the manuscript. Also, S.S. and M.M.I. read and revised the manuscript. 
Funding: To carry out the fieldwork, the first author received travel funding from the Doctoral Programme in Interdisciplinary Environmental Science (DENVI), University of Helsinki, Finland.

Acknowledgments: We sincerely thank the hilsa fishers and other stakeholders interviewed in this research. We acknowledge USAID funded Enhanced Coastal Fisheries in Bangladesh (ECOFISH-Bangladesh), an activity jointly implemented by WorldFish and Department of Fisheries (DoF), Ministry of Fisheries and Livestock, Bangladesh for all the logistical help they provided during data collection. We are grateful to Päivi Haapasaari, James Tobey and Aili Pyhälä for the constructive comments and feedback on earlier versions of the manuscript. We would like to thank David Huisjen, Jr. for his assistance in improving English of the paper.

Conflicts of Interest: The authors declare no conflict of interest. The founding sponsors had no role in the design of the study; in the collection, analyses, or interpretation of data; in the writing of the manuscript and in the decision to publish the results.

\section{References}

1. Coria, J.; Sterner, T. Natural resource management: Challenges and policy options. Annu. Rev. Resour. Econ. 2011, 3, 203-230. [CrossRef]

2. Holland, M.M. Ensuring sustainability of natural resources: Focus on institutional arrangements. Can. J. Fish. Aquat. Sci. 1996, 53, 432-439. [CrossRef]

3. Berkes, F.; Folke, C. Linking social and ecological systems for resilience and sustainability. In Linking Social and Ecological Systems: Management Practices and Social Mechanisms for Building Resilience; Cambridge University Press: Cambridge, UK, 1998; Volume 1.

4. Bavinck, M.; Pellegrini, L.; Mostert, E. Conflicts over Natural Resources in the Global South: Conceptual Approaches; CRC Press: Boca Raton, FL, USA, 2014.

5. Finkbeiner, E.M.; Oleson, K.L.; Kittinger, J.N. Social Resilience in the Anthropocene Ocean. In Conservation for the Anthropocene Ocean; Academic Press: Cambridge, MA, USA, 2017; pp. 89-106.

6. The State of World Fisheries and Aquaculture 2016: Contributing to Food Security and Nutrition for All. Available online: http:/ / www.fao.org/3/a-i5555e.pdf (accessed on 7 August 2018).

7. Finkbeiner, E.M. The role of diversification in dynamic small-scale fisheries: Lessons from Baja California Sur, Mexico. Glob. Environ. Chang. 2015, 32, 139-152. [CrossRef]

8. Shamsuzzaman, M.M.; Islam, M.M.; Tania, N.J.; Al-Mamun, M.A.; Barman, P.P.; Xu, X. Fisheries resources of Bangladesh: Present status and future direction. Aquac. Fish. 2017, 2, 145-156. [CrossRef]

9. Fisheries Statistics of Bangladesh. Available online: http:/ / fisheries.portal.gov.bd (accessed on 8 August 2018).

10. Islam, M.M.; Mohammed, E.Y.; Ali, L. Economic incentives for sustainable hilsa fishing in Bangladesh: An analysis of the legal and institutional framework. Mar. Policy 2016, 68, 8-22. [CrossRef]

11. Begum, M.; Bhowmik, S.; Juliana, F.M.; Hossain, M.S. Nutritional Profile of Hilsa Fish [Tenualosa ilisha (Hamilton, 1822)] in Six Selected Regions of Bangladesh. J. Nutr. Food Sci. 2016, 6, 2. [CrossRef]

12. Islam, M.M.; Chuenpagdee, R. Nomadic Fishers in the Hilsa Sanctuary of Bangladesh: The Importance of Social and Cultural Values for Wellbeing and Sustainability. In Social Wellbeing and the Values of Small-Scale Fisheries; Springer: Cham, Switzerland, 2018; pp. 195-216. [CrossRef]

13. Bhaumik, U. Review of global studies on food, growth and maturity profile of Indian shad (Tenualosa ilisha). Int. J. Curr. Res. Acad. Rev. 2015, 3, 127-139.

14. BOBLME. Report of the Hilsa Working Group Meeting, 10-11 October 2011, Dhaka, Bangladesh. Available online: www.boblme.org/documentRepository / BOBLME-2011-Ecology-20.pdf (accessed on 6 August 2018).

15. BOBLME. Report of the Hilsa Fisheries Assessment Working Group II, 24-25 April 2012, Mumbai, India. BOBLME-2012-Ecology-10. pp. 1-34. Available online: www.boblme.org/documentRepository / BOBLME2012-Ecology-10.pdf (accessed on 6 August 2018).

16. Milton, D.A. Status of Hilsa (Tenualosa ilisha) Management in the Bay of Bengal: An Assessment of Population Risk and Data Gaps for More Effective Regional Management; Report to FAO; Bay of Bengal Large Marine Ecosystem Project: Phuket, Thailand, 2010; Volume 15, p. 70.

17. Sahoo, A.K.; Wahab, M.A.; Phillips, M.; Rahman, A.; Padiyar, A.; Puvanendran, V.; Behera, B.K. Breeding and culture status of Hilsa (Tenualosa ilisha, Ham. 1822) in South Asia: A review. Rev. Aquac. 2018, 10, $96-110$. [CrossRef]

18. Adger, W.N. Social and ecological resilience: Are they related? Prog. Hum. Geogr. 2000, 24, 347-364. [CrossRef] 
19. Berkes, F. Evolution of co-management: Role of knowledge generation, bridging organizations and social learning. J. Environ. Manag. 2009, 90, 1692-1702. [CrossRef] [PubMed]

20. Al Mamun, A. Leadership in Community-Based Organizations: What Fisheries Comanagement Teaches Us? Int. J. Soc. Sci. Res. 2015, 3, 172-189. [CrossRef]

21. Cote, M.; Nightingale, A.J. Resilience thinking meets social theory: Situating social change in socio-ecological systems (SES) research. Prog. Hum. Geogr. 2012, 36, 475-489. [CrossRef]

22. Ostrom, E. A general framework for analyzing sustainability of social-ecological systems. Science 2009, 325, 419-422. [CrossRef] [PubMed]

23. Berkes, F. Environmental Governance for the Anthropocene? Social-Ecological Systems, Resilience, and Collaborative Learning. Sustainability 2017, 9, 1232. [CrossRef]

24. Béné, C.; Evans, L.; Mills, D.; Ovie, S.; Raji, A.; Tafida, A.; Andrew, N. Testing resilience thinking in a poverty context: Experience from the Niger River basin. Glob. Environ. Chang. 2011, 21, 1173-1184. [CrossRef]

25. Ommer, R.E.; Perry, R.I.; Murray, G.; Neis, B. Social-ecological dynamism, knowledge, and sustainable coastal marine fisheries. Curr. Opin. Environ. Sustain. 2012, 4, 316-322. [CrossRef]

26. Nayak, P.K.; Oliveira, L.E.; Berkes, F. Resource degradation, marginalization, and poverty in small-scale fisheries: Threats to social-ecological resilience in India and Brazil. Ecol. Soc. 2014, 19, 73. [CrossRef]

27. Glaser, M.; Krause, G.; Oliveira, R.S.; Fontalvo-Herazo, M. Mangroves and people: A social-ecological system. In Mangrove Dynamics and Management in North Brazil; Springer: Berlin/Heidelberg, Germany, 2010; pp. 307-351. [CrossRef]

28. Holling, C.S. Resilience and stability of ecological systems. Annu. Rev. Ecol. Syst. 1973, 4, 1-23. [CrossRef]

29. Perrings, C. Resilience and sustainable development. Environ. Dev. Econ. 2006, 11, 417-427. [CrossRef]

30. Vayda, A.; McCay, B. New directions in ecology and ecological anthropology. Annu. Rev. Anthropol. 1975, 4, 293-306. [CrossRef]

31. Masten, A.S.; Obradovic, J. Disaster preparation and recovery: Lessons from research on resilience in human development. Ecol. Soc. 2008, 13, 9. [CrossRef]

32. Peterson, G. Political ecology and ecological resilience: An integration of human and ecological dynamics. Ecol. Econ. 2000, 35, 323-336. [CrossRef]

33. Brown, K. Global environmental change I: A social turn for resilience? Prog. Hum. Geogr. 2014, 38, $107-117$. [CrossRef]

34. Bradley, D.; Grainger, A. Social resilience as a controlling influence on desertification in Senegal. Land Degrad. Dev. 2004, 15, 451-470. [CrossRef]

35. Maguire, B.; Hagan, P. Disasters and communities: Understanding social resilience. Aust. J. Emerg. Manag. 2007, 22, 16.

36. Fauzi, A.; Anna, Z. Social resilience and uncertainties: The case of small-scale fishing households in the north coast of Central Java. MAST 2010, 9, 55-64.

37. Marshall, N.A. Understanding social resilience to climate variability in primary enterprises and industries. Glob. Environ. Chang. 2010, 20, 36-43. [CrossRef]

38. Sutton, S.; Tobin, R. Social resilience and commercial fishers' responses to management changes in the Great Barrier Reef Marine Park. Ecol. Soc. 2012, 17, 6. [CrossRef]

39. Marshall, N.A.; Fenton, D.M.; Marshall, P.A.; Sutton, S.G. How resource-dependency can influence social resilience within a primary resource industry. Rural Sociol. 2007, 72, 359-390. [CrossRef]

40. Davidson, D.J. The applicability of the concept of resilience to social systems: Some sources of optimism and nagging doubts. Soc. Nat. Res. 2010, 23, 1135-1149. [CrossRef]

41. Carpenter, S.; Brock, W.A. Spatial complexity, resilience, and policy diversity: Fishing on lake-rich landscapes. Ecol. Soc. 2004, 9, 8. [CrossRef]

42. Nelson, D.R.; Adger, W.N.; Brown, K. Adaptation to environmental change: Contributions of a resilience framework. Annu. Rev. Environ. Res. 2007, 32, 395-419. [CrossRef]

43. Berkes, F.; Ross, H. Community resilience: Toward an integrated approach. Soc. Nat. Res. 2013, 26, 5-20. [CrossRef]

44. Brown, K.; Westaway, E. Agency, capacity, and resilience to environmental change: Lessons from human development, well-being, and disasters. Annu. Rev. Envrion. Res. 2011, 36, 321. [CrossRef]

45. Brown, K. Resilience, Development and Global Change; Routledge: Abingdon, UK, 2015; 228p. 
46. Maclean, K.; Cuthill, M.; Ross, H. Six attributes of social resilience. J. Environ. Plan. Manag. 2014, 57, $144-156$. [CrossRef]

47. Tompkins, E.; Adger, W.N. Does adaptive management of natural resources enhance resilience to climate change? Ecol. Soc. 2004, 9, 10. [CrossRef]

48. Berkes, F.; Turner, N.J. Knowledge, learning and the evolution of conservation practice for social-ecological system resilience. Hum. Ecol. 2006, 34, 479. [CrossRef]

49. Anderies, J.M.; Folke, C.; Walker, B.; Ostrom, E. Aligning key concepts for global change policy: Robustness, resilience, and sustainability. Ecol. Soc. 2013, 18, 8. [CrossRef]

50. Carlsson, L.; Berkes, F. Co-management: Concepts and methodological implications. J. Environ. Manag. 2005, 75, 65-76. [CrossRef] [PubMed]

51. Islam, M.M.; Aktar, R.; Nahiduzzaman, M.; Barman, B.K.; Wahab, M.A. Social Considerations of Large River Sanctuaries: A Case Study from the Hilsa Shad Fishery in Bangladesh. Sustainability 2018, 10, 1254. [CrossRef]

52. Cinner, J.E.; Huchery, C.; MacNeil, M.A.; Graham, N.A.J.; McClanahan, T.R.; Maina, J.; Maire, E.; Kittinger, J.N.; Hicks, C.C.; Mora, C.; et al. Bright spots among the world's coral reefs. Nature 2016, 535, 416-419. [CrossRef] [PubMed]

53. Schlager, E.; Ostrom, E. Property-rights regimes and natural resources: A conceptual analysis. Land Econ. 1992, 68, 249-262. [CrossRef]

54. Leach, M.; Mearns, R.; Scoones, I. Environmental entitlements: Dynamics and institutions in community-based natural resource management. World Dev. 1999, 27, 225-247. [CrossRef]

55. Hasan, K.M.M.; Wahab, M.A.; Ahmed, Z.F.; Mohammed, E.Y. The Biophysical Assessments of the Hilsa Fish (Tenualosa ilisha) Habitat in the Lower Meghna, Bangladesh; Working Paper; IIED: London, UK, 2015; Available online: http:/ / pubs.iied.org/pdfs/16605IIED.pdf (accessed on 8 August 2018).

56. Islam, M.M.; Islam, N.; Sunny, A.R.; Jentoft, S.; Ullah, M.H.; Sharifuzzaman, S.M. Fishers' perceptions of the performance of hilsa shad (Tenualosa ilisha) sanctuaries in Bangladesh. Ocean Coast. Manag. 2016, 130, 309-316. [CrossRef]

57. Baxter, P.; Jack, S. Qualitative case study methodology: Study design and implementation for novice researchers. Qual. Rep. 2008, 13, 544-559.

58. Some Guidance on Conducting and Reporting Qualitative Studies. Available online: https://oro.open.ac. uk/48027/1/CAE\%20Editorial\%20on\%20qualitative\%20research\%2016-11-16\%20submitted.pdf (accessed on 8 August 2018).

59. Lambert, S.D.; Loiselle, C.G. Combining individual interviews and focus groups to enhance data richness. J. Adv. Nurs. 2008, 62, 228-237. [CrossRef] [PubMed]

60. Etikan, I.; Musa, S.A.; Alkassim, R.S. Comparison of convenience sampling and purposive sampling. Am. J. Theor. Appl. Stat. 2016, 5, 1-4. [CrossRef]

61. MacDougall, C.; Fudge, E. Planning and recruiting the sample for focus groups and in-depth interviews. Qual. Health Res. 2001, 11, 117-126. [CrossRef] [PubMed]

62. Mubaya, C.P.; Njuki, J.; Mutsvangwa, E.P.; Mugabe, F.T.; Nanja, D. Climate variability and change or multiple stressors? Farmer perceptions regarding threats to livelihoods in Zimbabwe and Zambia. J. Environ. Manag. 2012, 102, 9-17. [CrossRef]

63. Mason, M. Sample size and saturation in PhD studies using qualitative interviews. Forum Qual. Soc. Res. 2010, 11, 8. [CrossRef]

64. Miles, M.B.; Huberman, A.M.; Huberman, M.A.; Huberman, M. Qualitative Data Analysis: An Expanded Sourcebook; SAGE: Thousand Oaks, CA, USA, 1994; p. 373.

65. Hsieh, H.F.; Shannon, S.E. Three approaches to qualitative content analysis. Qual. Health Res. 2005, 15, 1277-1288. [CrossRef] [PubMed]

66. Elo, S.; Kyngäs, H. The qualitative content analysis process. J. Adv. Nurs. 2008, 62, 107-115. [CrossRef] [PubMed]

67. Graneheim, U.H.; Lundman, B. Qualitative content analysis in nursing research: Concepts, procedures and measures to achieve trustworthiness. Nurse Educ. Today 2004, 24, 105-112. [CrossRef] [PubMed]

68. Kalikoski, D.C.; Allison, E.H. Learning and Adaptation: The Role of Fisheries Co-management in Building Resilient Social-Ecological Systems. In Adaptive Capacity and Environmental Governance; Springer: Berlin/Heidelberg, Germany, 2010; pp. 69-88. 
69. Jentoft, S.; Pascual-Fernandez, J.J.; de la Cruz Modino, R.; Gonzalez-Ramallal, M.; Chuenpagdee, R. What stakeholders think about marine protected areas: Case studies from Spain. Hum. Ecol. 2012, 40, 185-197. [CrossRef]

70. Mascia, M.B.; Claus, C.; Naidoo, R. Impacts of marine protected areas on fishing communities. Conserv. Biol. 2010, 24, 1424-1429. [CrossRef] [PubMed]

71. Bennett, N.J.; Dearden, P. Why local people do not support conservation: Community perceptions of marine protected area livelihood impacts, governance and management in Thailand. Mar. Policy 2014, 44, 107-116. [CrossRef]

72. Pita, C.; Pierce, G.J.; Theodossiou, I. Stakeholders' participation in the fisheries management decision-making process: fishers' perceptions of participation. Mar. Policy 2010, 34, 1093-1102. [CrossRef]

73. Jentoft, S.; McCay, B. User participation in fisheries management: Lessons drawn from international experiences. Mar. Policy 1995, 19, 227-246. [CrossRef]

74. Marine Conservation and Coastal Communities: Who Carries the Costs? A Study of Marine Protected Areas and Their Impact on Traditional Small-Scale Fishing Communities in South Africa. Available online: www.aquaticcommons.org/1563/1/Samudra_mon4.pdf (accessed on 20 June 2018).

75. Engel, S.; Pagiola, S.; Wunder, S. Designing payments for environmental services in theory and practice: An overview of the issues. Ecol. Econ. 2008, 65, 663-674. [CrossRef]

76. Hanna, S.S. User participation and fishery management performance within the Pacific Fishery Management Council. Ocean Coast. Manag. 1995, 28, 23-44. [CrossRef]

77. Purcell, S.W.; Pomeroy, R.S. Driving small-scale fisheries in developing countries. Front. Mar. Sci. $2015,2,44$. [CrossRef]

78. Chaffin, B.C.; Gosnell, H.; Cosens, B.A. A decade of adaptive governance scholarship: Synthesis and future directions. Ecol. Soc. 2014, 19, 56. [CrossRef]

79. Allison, E.H.; Ellis, F. The livelihoods approach and management of small-scale fisheries. Mar. Policy 2001, 25, 377-388. [CrossRef]

80. Sowman, M.; Sunde, J.; Raemaekers, S.; Schultz, O. Fishing for equality: Policy for poverty alleviation for South Africa's small-scale fisheries. Mar. Policy 2014, 46, 31-42. [CrossRef]

81. Rahman, M.; Rahman, M.M.; Hasan, M.M.; Islam, M.R. Livelihood status and the potential of alternative income generating activities of fisher's community of Nijhumdwip under Hatiya Upazilla of Noakhali district in Bangladesh. Bangladesh Res. Publ. J. 2012, 6, 370-379.

82. Ahlin, C.; Jiang, N. Can micro-credit bring development? J. Dev. Econ. 2008, 86, 1-21. [CrossRef]

83. Chowdhury, M.J.A.; Ghosh, D.; Wright, R.E. The impact of microcredit on poverty: Evidence from Bangladesh. Prog. Dev. Stud. 2005, 5, 298-309. [CrossRef]

84. Rahman, A. Microcredit Initiatives for Equitable and Sustainable Development: Who Pays? World Dev. 1999, 27,67-82. [CrossRef]

85. Community Participation in Fisheries Management in Tanzania. Available online: https://ir.library. oregonstate.edu/concern/conference_proceedings_or_journals/1c18dg58c (accessed on 20 June 2018).

86. Aranda, M.; Murillas, A.; Motos, L. Command-and-control quota-based regimes. Dev. Aquac. Fish. Sci. 2006, 36, 143-161.

87. Johannes, R.E.; Freeman, M.M.; Hamilton, R.J. Ignore fishers' knowledge and miss the boat. Fish Fish. 2000, 1, 257-271. [CrossRef]

88. Silvano, R.A.; Valbo-Jørgensen, J. Beyond fishermen's tales: Contributions of fishers' local ecological knowledge to fish ecology and fisheries management. Envrion. Dev. Sustain. 2008, 10, 657. [CrossRef]

89. Beaudreau, A.H.; Levin, P.S. Advancing the use of local ecological knowledge for assessing data-poor species in coastal ecosystems. Ecol. Appl. 2014, 24, 244-256. [CrossRef] [PubMed]

90. Aswani, S.; Hamilton, R.J. Integrating indigenous ecological knowledge and customary sea tenure with marine and social science for conservation of bumphead parrotfish (Bolbometopon muricatum) in the Roviana Lagoon, Solomon Islands. Environ. Conserv. 2004, 31, 69-83. [CrossRef]

91. Mozumder, M.M.H.; Shamsuzzaman, M.M.; Rashed-Un-Nabi, M.; Karim, E. Social-ecological dynamics of the small-scale fisheries in Sundarban Mangrove Forest, Bangladesh. Aquac. Fish. 2018, 3, 38-49. [CrossRef]

92. Mamun, A.A. Traditional Ecological Knowledge and Its Importance for Conservation and Management of Freshwater Fish Habitats of Bangladesh. Master's Thesis, Natural Resources Institute, University of Manitoba Winnipeg, Winnipeg, MB, Canada, January 2007. 
93. Khan, M.A.; Alam, M.F.; Islam, K.J. The impact of co-management on household income and expenditure: An empirical analysis of common property fishery resource management in Bangladesh. Ocean Coast. Manag. 2012, 65, 67-78. [CrossRef]

94. Sultana, P.; Thompson, P. Gender and local floodplain management institutions: A case study from Bangladesh. J. Int. Dev. 2008, 20, 53-68. [CrossRef] 